\title{
EXFOLIATIVE-CYTOLOGICAL AND PATHO-HISTOLOGICAL STUDY ON EPIPHARYNGITIS OF RABBITS
}

\author{
By \\ Mizuo ICHIKAWA, Setsuo ARATA and Tetsuji NARA \\ From the Department of Oto-Rhino-Laryngology, School of Medicine, Tokyo \\ Medical and Dental University (Director: Prof. S. Horiguti)
}

As Prof. Horiguti has often pointed out, epipharyngitis has a close relation with various symptoms such as mild fever, headache, dizziness of unknown causes, and with many diseases such as nasal allergy, asthma, and other allergic diseases, orthostatic dysregulation in children, some cardiac diseases, rheumatism, stomatitis aphthosa, pyorrhoea alveolaris and so on. But this relationship has not been indicated clearly and widely up until the present time. The reason is, we think, that the observation of the epipharynx was difficult and that the competent diagnostic method was not established to decide the definite inflammation of the epipharynx.

For the diagnosis of epipharyngitis, we have been practising the observation of pain and bleeding on touch of cottentipped applicator on the epipha rynx, and smear of epipharyngeal surface.

The purpose of our experiment was to clarif: the relation between the inflammatory change 0 epipharyngeal surface and its smear.

We poured $0.3 \mathrm{cc}$ of $5 \%$ formalin into epipharyn of the rabbits to cause acute epipharyngitis experi mentally and compared smear of epipharyngeal su rface with its histological picture of each stage.

As a result of this experiment, we found tha the findings of the smear was parallel the histolo gical picture.

Therefore, we believe that state of each stage of epipharyngitis can be surmised by observing it: smear.

\section{家鬼鼻咽腔炎の涂離細胞学的並びに病理組織学的研究}

\author{
東京医科齿科大学耳围咽唍科学教室（指導：堀口申作教授）

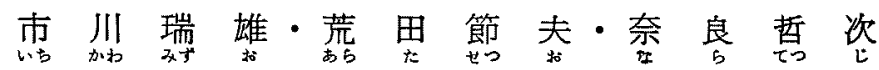

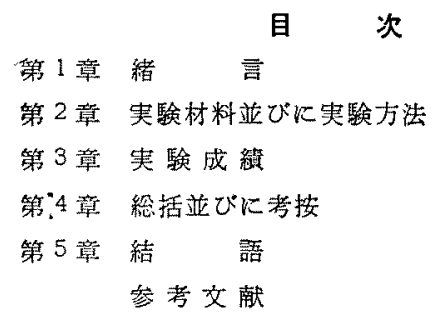

\section{第 1 章 緒}

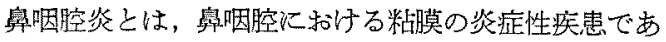
る.われわれは虫咽腔炎が単に鼻咽腔のみならず全身各 一哪の色々な種類の疾患と密接な関係を有することを多く
の臨床的事実によつて明らかにした，例总ば，原因不明 の微熱や頭痛，めまい，小监科に括ける 起立性 調節障 害，番アレルギーや喘息その他のフレルギー疾患，ロ1 マ，ある種の心疾患，アフタ性口内炎ならぴに菌槽澧涯 などその関連する所は非常に広範に亘つている。しかる 飞鼻㸶腔はその解剖学的䅇造上，非常に観察の困難な堨 所で，その部の病恋は後奥鏡や鼻咽腔鏡によつて実体の 一部を観察し得るにとどまり，その炎症の真の様相をと らえることは決して容易ではない，唒咽腔炎が上記の如 く極めて重大な意義を有する疾患であるにるかかから ず，今日迄ほとんと研究の対象とならなかつた理由は正 
ここにあると考えられるのである．おが教室において

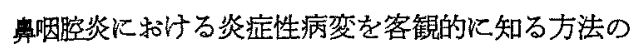
らとして得離細胞学的検查を応用してきた。この方法 番咽腔炎の実態を把握するために極めて便利な方法で る. 例えば，村上の報告した如く，単に鼻乃至咽頭綿 により鼻咽腔粘膜を軽〉擦過するのみで標本の採取は 能である.この採取標本比より，鼻咽腔炎の日々の变 の様相を確塞炡光ることが可能であるが，しか儿臨 的人体材料比いては，炎症の経過をその始めから系 的に観察することは不可能であるので，今日われわれ 界咽腔が正常であると考えられる家鬼に，実験的に急 楀咽膑炎を港起せしめ，各時期における鼻咽腔粘膜の

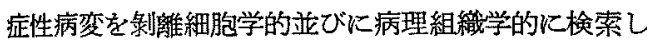
ので，その結果を報告する次第である．

\section{第 2 章 実験材料並びに実験方法}

実験材料

实験動物は10日間以上一定の食飼で隔離飼育した体 $2.3 \mathrm{~kg}$ 前後の健常成熟 婎性白色家鬼 53 羽を使用儿 なお実験は 12 月より翌年 10 月迄の間に行つた。

実験方法

家鬼を固定台に仰卧位に固定し，右側鼻孔より細いポ エチレン管を鼻咽腔まで挿入する。つで $5 \%$ ホルマ 液 $0.3 \mathrm{cc}$ を、ツベルクリン用注射器を用いて，注射 をポリェキレン管に接続し，ゆるやかに液を楀咽腔内 注入する. かくして家兔に急性鼻咽腔炎を萑起せし , 1 時間後， 3 時間後，6時間後，12 時間後， 24 時間 ，3日後，7日後，14日後，21日後，28日後の各群 分け，空気柽塞により家鬼を死亡させ，直ちに断頭し

な技無処置のものを対照群とした。ついで巻綿子を いて，咽頭側より周因粘膜に巻綿子が触れないように 意しつつ，右側畀咽腔粘膜，すなわら，右側軟口蓋背 ならびに 側上壁部を軽く擦過して上皮細胞を採取し

直ちに採物グラスに塗布し，エーテル・フルコール 固定した. 染色は papanicolaou 染色並びに Hämat. ylin Eosin 重染色を行つた。 また病理組織学的検索 ため，身咽腔粘膜を周囲骨部より管状に除去し，直ち $10 \%$ ホルマリン液に固定し，型の如く漸強アルコー こて脱水， パラフインを bつて包理し，前頭断にて 因腔部の連緢切片を作製した。染色は Hämatoxylin sin 重染色並びに PAS 染色の二㥞を行つた。 かく て左側鼻咽腔に残存せる上皮細胞を病理組織学的に観 した，また鼾腔に打るる炎症の程度を知るため，番孔

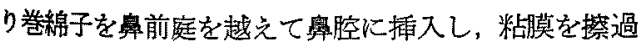

し, 上述の如き方法にて剥離細胞学的検索を行い鼻咽腔 のものと比較した。

\section{第3 章 実験 成 精}

第 1 項 臨床的所見の概要

仰臥位に固定された家束の鼻咽腔にホルマリン液を注 入すると，四抆弱直し，心音は微弱となり，数秒の間心 音聴取不能となりショック様症状を呈する，多くの場 合，動物は 2 3 分位でその状態より恢復し，固定台上 り解放すると，軽い噴㗪発作をなし，運動不活発とな る、そして動物箱の隅で意気鋭沈する，多くの動物は， ホルマリン液注入後鼻孔は湿潤となり，24時間後に至 り，鼻孔の湿潤は增し，噴德により多量の膿性鼻漏を認 める. 鼻咽腔内の膿汗量の程度に応じて呼吸運動は障害 される，多数の動物では，食欲減退や体温上昇が認めら れ，障害の只大なる場合には，下痴症状を呈する。3〜5 日に至り，鼻孔の湿潤は軽度になり，多くの場合，食欲 減退，呼吸運動障害などの諸症状は恢復するも，ごく少 数に招いて一般状態が悪化し，死亡するものるある. 生 存例に打いては，1 週間後に臨床的に大きな变化は諗め られず，2 週間後には全く常態に復したように思われ た.

第 2 項 剥離細胞学的並びに病理組織学的所見

1. 無処置対照群

i) 正常線毛細胞の剶離細胞学的所見 (写真 1)

鼻咽腔粘膜から得られた塗珠標本に見られる細胞の大 多数の線毛細胞で，艺の間に少数の杯状細胞が混在し，

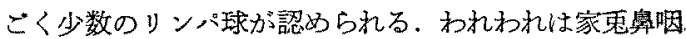
腔の線毛細胞を形態学的に次の 3 つの型に分類してみ た.

I 型は標潐形細胞で，小皮縁部が円柱状の細胞体の横 径亡等しいか，ごくわずが狭く，核は縦棈円形であ る. 【型は細長型細胞で， 3 䅜中，細胞体は最も細長 々，小皮縁の幅も狭く，核は長棈円形で，細胞体の横径 は概して小皮縁部上り狭い、西型は二等辺三角型細胞 で，3種中，細胞体は最も幅広く，核は楕円形である。 以上のような線毛細胞の他に，細胞質汇粘液を蔵せる杯 状細胞が認められる。.大きさは標潐形細胞上同じ位で， 細胞底に円形あるいは杯状の核を有する。

ii）正常粘膜の組織学的所見 (写真 2)

上皮は多列性 線毛円柱細胞で，その間に杯状細胞が 所々に混在する，上皮層化接して璂底膜があり，その下 には線維性の固有層がある．固有層にはごくわずかのり ンパ球と形質細胞の浸潤があり，少数の毛細血管が認め。 
られる。甪咽腔は番腔側，すなわち，前部に扎いては上 皮の層が少くなり，杯状細胞が比较的增加する，咽頭側 では多列性円柱上皮よりなり，血管並びに腺汇富み，耳 管開口部附近ではリンパ滤胞がみられる。㐬た，軟口蓋 背側では，咽頭の移行部附近において扇平上皮に移行す る.

2. ホルマリン液注入 1 時間後

i) 剥離細胞学的所見 (写真 3 )

線毛細胞の線毛は，しばしば不規則に束权られて捕 り，上皮は娳離され易く、ばらばらになり，細胞質内に 恃大小の空泡変性が認められる. 搪張せる少数の杯状細 胞, わずかのリンパ球が認められる他, 少数の多核白血 球が混在している。

ii) 病理組織学的所見 (写真 4 )

線毛細胞の線毛は不規則に㠜集し，細胞質の小皮縁に 近い部分で軽度の变性が生じ，上皮細胞間には軽度の弛 緩が認められる，固有層には軽度の充血，水腫，細胞浸 潤が認められる。

3. ホルマリン液注入 3 時間後

i) 剝離細胞学的所見 (写真 5 )

上皮細胞は剝離され易く、ばらばらになり，線毛細胞 の輪廓はやや不明膫となり，多くの細胞は変形し，細胞 質内には著明な空泡変性が生じ，核膜も不明嘹となる。 杯状細胞は拉張が增し，多数の多核白血球の遊出が認め られる。

ii) 病理緝織学的所見 (写真 6$)$

上皮細胞の膨化は著明で，細胞間の弛緩は增強し，一 部に上皮剝雜，多数の白血球浸潤などが認めら九る。固

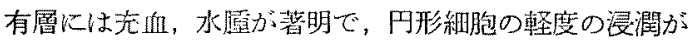

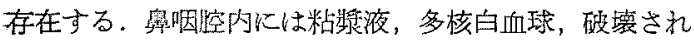
た剝離上皮が認められる。

4. ホルマリン液注入6時間後

i) 剥離細胞学的所見 (写真 7)

多数の多核白血球が出現している。線毛細胞の变性お よび変形は著明になり，線毛の不規則な垡失，細胞質の 萠壊，核の膨大㧍よび核融解，核瀑縮などの像がみられ る.

ii) 病理組織学的所見 (写真 8 )

線毛細胞卡よび杯状細施の脱落崩朢が高度にみられ， 基宣膜上に舖充細胞が認められるにすぎない，固有層で は血管の搪張，水尰，円形細胞の浸潤が著明になる，鼻 咽腔内には多数の多核白血球や崩壤上皮細胞が認められ る.
5. ホルマリン液注入 12 時間後

i) 永離細胞学的所見 (写真 9 )

上皮細胞には正常な形を有するものははとんどなく， 細胞質，核とむに高度な変化を示している．上皮細胞は 壊れ易い，多数の多核白血球が存在する。

ii) 病理組織学的所見 (写真 10)

上皮紐胞の脱落立びに破壊が著明で，一層の補充細胞 が基底膜の上に存在しているに過ざない，固有㬝では血 管の㹡張, 水運, 円形細胞の泿潤が著明に認められる。 澚咽腔内には多数の多核白血球，少数のリン゙球，赤血 球などが存在する。

6. ホルマリン液注入 24 時間後

i) 䄻離細胞学的所見 (写真 11)

正常な形を有する線毛細胞は存在せず，少数の円形な いし不規則な棈円形の核を有し，細胞質の不明瞭な細胞 が認められ，一部のものでは核の融解もみられる.大多 数恃多核白血球である。

ii) 病理組織学的所見 (写真 12)

上皮細胞は破壤脱落し，補充細胞がところどころに牫

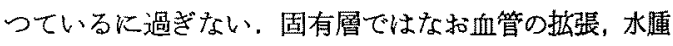
が著明で，円形細胞浸潤が認められる、病变の強い一部 には磨爛乃至濽㢜が生ずる，鼻㸶腔内には多数の多核白 血球や細胞崩壊物が認められる。

7. ホルマリン液注入 3 日後

i) 剝離細胞学的所見 (写真 13)

輸廓が明膫で核の色犋に富む細胞が少数存在するが， なお多数の多核白血球が認められる。

ii) 病理組織学的所見 (写真 14)

粘膜面には広䈯な磁爛が生じているが，すでとその隣 接部からは上皮の再生像が認められる，固有層ではな拉 血管の掋張，水藏，少数の白血球括よび組蟣球の浸潤が 認められる。

8. ホルマリン液注入 7 日後

i) 剝離細胞学的所見 (写真 15)

翰廓明瞭な多角形または円柱上皮細胞がやや增加して いるか゚，まだ杯状細胞は認められない，な括中等数の多 核白血球が認められる。

ii) 病理組織学的所見 (写真 16)

上皮細胞の再生は著明であるが，配列はむだ不规則 で，楾毛を有する細胞，杯状細胞は認められず，队柱細 胞が主である，固有層では毛細血管の新生，線維茅細胞 の增殖が認められる。鼻咽腔内にはなお少量の澧计が嵒 められる。 
9. ホルマリン液注入 14 日後

i) 㔀離細胞学的所見 (写真 17)

少数の正常な形を有する線毛細胞が出現し，少数の円 柱細胞，杯状細胞が認められるようになつた。な抄数 の多核白血球，リンパ球が認められる。

ii) 病理組織学的所見 (写真 18)

再生上皮の分化が進み，上皮層は正常な構造に近くな る.才なかち，比較的背の低い線毛細胞，杯状細胞加認 められる，炎症性変化は忹とんど消失するお，な細胞 の配列は多少不規則である，固有周では水尰が消退，細 胞浸閏す減退した，奥胭腔内には脿は認められない。

10. ホルマリン液注入 21 日後

i) 剥離細胞学的所見 (写真 19)

かなり多数の正常の線毛を有する線毛細胞と少数の杯 状細胞が認められる。線毛細胞は一般に，細胞体の長佳 が短い．多核白血球は消失したが，少数のリンパ球が認 められる．核の下部の細胞体が不完全なため二等辺三角 形の形を示寸細胞方多い。

ii) 病理組織学的所見 (写賣 20)

上皮層はほとえど正常に近い搆造を示している，固有 層では资症性変化ははとんど消失している舆㸶腔内には 膿汁は認められない。

11. ホルマリン液注入 28 日後

i) 剝離細胞学的所見 (写真 21$)$

線毛細胞多多数の線毛を有方るむのが多く，楾胞体も 核も細長くなり，正常な形を示している．少数の杯状細 胞やリンパ球が認められる。

ii) 病理組蟣学的所見 (写真 22)

上皮層はほとえど正常な粘膜上皮の秧造を示してお り，固有尿に和いても炎症性変化は消失している。

\section{第 4 章 総括並びに考按}

家兔急性學咽腔炎における以上の所見を剥離細胞学的 並びに病理組織学的に総括すると次の如くである。

1. 彔摛隹細㴔学的所見

主な种胞の消長は第1図化みられるごとく，炎症の初 期，すなわち，I〜3 時間頃では楾毛細胞は 品泡变性に おちちいり，上皮の細胞間結合が弛緩をきたすため絸胞は 非常に剝離されやすくなり，ばらばらに分れた上皮細胞 が多数出現する．6時間後になると，楾毛細胞の变性は さらに著明になり，細胞質は融解し，核もまた膨化ある

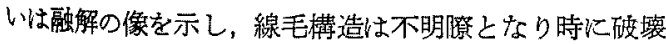
消失する，細胞の小皮縁多不明膫となる，やがて上皮細 胞の数は減少する。12時間後には上皮細胞の破壊が著

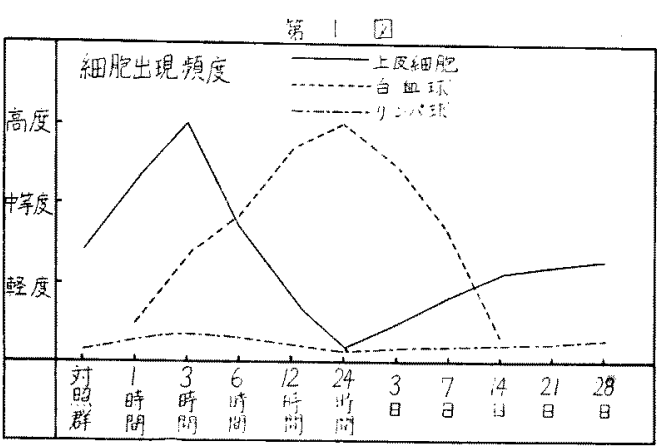

明になり，核の崩摆像がみられる。正常な形を有する線 毛細胞はほとえど認められない，24時間後には上皮細 胞数は非常に滅少し，細胞頃が醊壊変形された少数の細 胞が認められるにすぎない３日後よりほ添棈円形の核 と空泡に富吉細胞質を有する細胞が出現する。7日目に

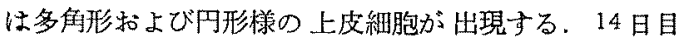
に瑔毛稩胞が管められるよらになるが，比較的背の低

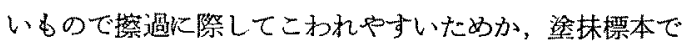
はその数はあまり多くない，その他少数の杯状細胞るみ られるよらになつた。2 21 日目には上皮細胞の 数はかな り增し，線毛細胞や杯状細胞が多数認められる。これら の上皮細胞は28日目にはほとんぞ正常に近い像を示す ようになつた。浸出細胞は主に多核白血球で，1時間後 より出現し，その数は次第に增加し，24時間目には最 も多く出現し，以後次第に減少し，14日後まで認めら れた。リンハ球は上皮細胞像の恢復せる $21 ， 28$ 日後に 軽度の覜加を示した。

\section{2. 病理組織学的所見}

本实歌に拈ける剝離細胞学的所見と，各時期における 粘獏病变の病理組織学的所見との間にどのような相關関 係があるであろうか，病理組織学的所胃として1時間後 では上皮層が倝度の变化をらけ，線毛細胞の線毛部の凝 集化と同時に，細胞間結合の軽度の拗緩像および分议が 盛んになるため杯状細胞の拡張などがみられる．固有層 には軽度の夺血，水腫が認められる．3時間後には上皮

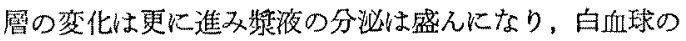
奥咽腔内遊超が多数みられるよらになる。6時間後には

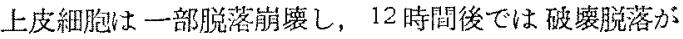
著明で，得咽腔内には膿性分泌物が認められる。24 時

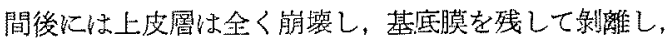

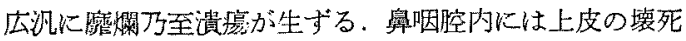

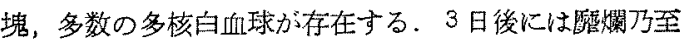


潰㿋の隣接部より上皮の再生が認められ，上皮の再生部 は重層扁平上皮の構造を示す 固有層にはかなりの細胞 漫潤が認められる。7日目には上皮層は多列性円柱上皮 となる．固有層に和ける病変は軽度になる，14日目に は上皮層は細胞の分化が進み，正常に近い線毛細胞，杯 状細胞が認められるようになるが，配列はまた不規則で ある。21 日目には上皮層の配列は規則的になり，ほと んど正常の上皮虽の猜造を示す。２8日目汇上上皮層拉 よび固有層ともに正常の構造を示す

家鬼の 鼻咽腔内に $5 \%$ ホルマリン液を注入した場合 に，化学的の鼻咽㬵炎を起すが，この際の鼻咽䐋炎の時 間的経過を剝離細胞学的並びに病理組織学的に榆索する

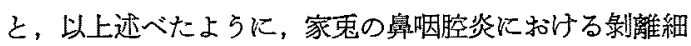
胞学的所見が，粘膜の病理組織学的所見之かなり明らか な平行的関係を示している。このことから少くとも家鬼 鼻㸶腔炎においては，剥離細胞の染抹所見によつてその 組織学的所見を類推することができる．この実験は人体 材料によつてわれ初れが日常検討しているところの鼻咽 腔上皮塗抹標本がその組織とどの程度の平行性がある か，换言すれば，人体鼻咽腔上皮塗抹標本像にどの程度 の信蜸性があるかということを考えたものである。もち ろん実験的に起した家鬼の病変と人の鼻咽腔炎との間に 必ずしも平行性があるものとは考えられないにしても，

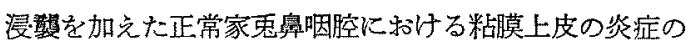
治癒過程を観察して，一つの法則を見出して的くことは 今後の奥咽腔粘膜上皮の炎症性変化の観察㥛好重要 なことであると教えるのである。

\section{第 5 章 結 語}

家洍の鼾咽腔に 5\% ホルマリン液 0.3cc を注入し，奏 験的化急性鼻咽腔炎を若起させ，各時期における鼻胭腔 粘膜病変の再生過程を剥離細胞学的ならびに病理組織学 的に研究し，次のごとき結論を得た。

1. 線毛細胞に打ける变性はすでにホルマリン液注入 1 時間後より認められ，同時に上皮細胞問結合の弛緩が 生ずるため，炎症の初期には最も多くの上皮細胞が認め られた。

2. 上皮細胞の炎症像は注入 24 時間後に最も強く， 上皮細胞の崩壤が著明に認奶られた。

3. 線毛細胞の再生は注入3日目上り始交り，7日目 に不規則な多角形乃至円柱細胞となる。
4. 線毛を有する上皮細胞は注入 14 日後より認めら れ，21日目には正常に復する。

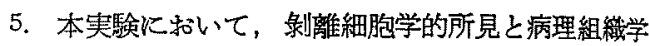
的所見との間に，かなりの平行的関係を見出すことがで きたので, 剥離細胞学的所見より鼻胭腔战莫に就子る病 変を推定することができるものと考光る.

\section{參考文献}

1) Brian, K: Die histologischen Veränderungen der Nasenschleimhaut nach Formalinadaptation und gekreuzter Resistenzsteigerung, Acta oto-laryng., 52, 429, $1960 . \quad$ 2) Burian, $K$. : Über der Restitutionshlähigkeit des Flirme epithels der Nase nach totaler Zerstörung des Epithels, Z. Laryng Rhinol. Otol., 39, 387, 1960. 3) Messerklinger, W.: DieSchleimhaut der oberen Luftwege im Blickfeld neuerer Forschung, Arch. f. O.N.K. hk., 173, 1, 1958. 4) Probst, R., u. Pfartz, C.R.: Über cytologische. Diagnostik in der Oto-Rhino-Laryngologie, Arch.f. O.N.K. hk., 164, 197, 1953. 5) Theobald, W.H.: Associated symptomatology of the epipharynx, Ann. O.R.L., 57, 678, 1948 6 6) 渡辺勤: 位相美㩆徽镜

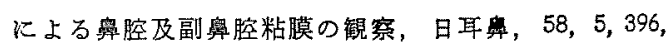

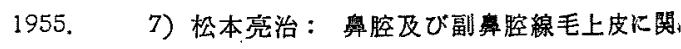
寸る研究，日耳率，61，11，1856，1958，8）堀口申作： 楀咽腔炎の現わす諸症状について，耳展，1，2，50， 1958.99)幸坂十四男：位相差顕徽鏡に上る上颚洞， 粘膜線毛上皮細胞の钼察，日耳，62，1１2，1959，

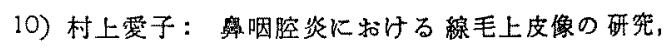
日耳厸，63，3，757，1960. 11) 谷崎須磨一：上㫬頭. 部の病理組織学的研究, 補遗耳展, 4, 補 1，71，1961.

12）八木研三：線毛上皮細胞の電子㩆微鏡的研究，耳鼻臨，54，1，43，1961.

稿を終るに当り，䅂始御孯第なる御指導と御 校閲を睗つた恩師堀口申作教授並びに秋吉正豊 教授に梁甚なる感謝の意を表する。

本諭交の要旨は，昭和36年第 383 回日本耳 咽喉科学会関東地方会において器表した。

（原稆到着＝昭和 38.11.14日） 
写真 1 正常家鬼鼻咽腔線毛上皮細胞

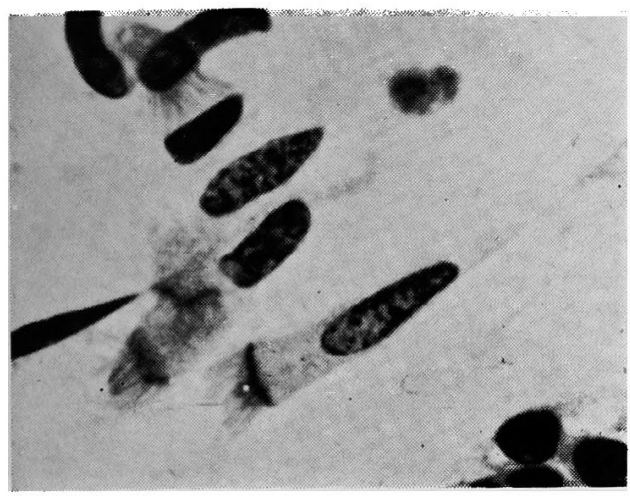

写真 3 注入 1 時間後

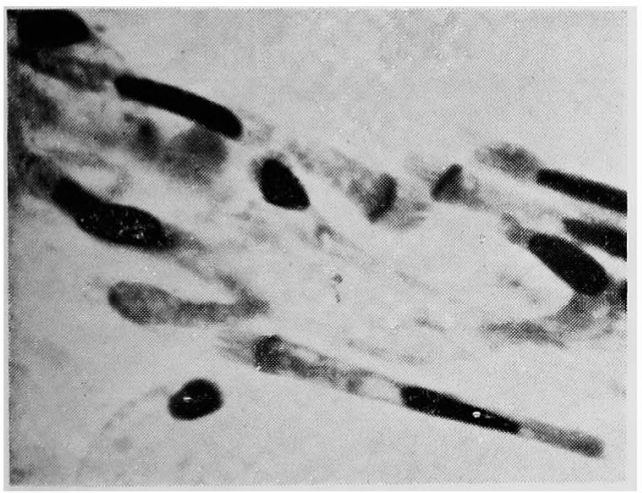

線毛は不規則に束ねられ，細胞質内に大小の空泡 変性が見られる。.上皮は剥離され易くなるためば らばらになる傾向がある。

写真 5 注入 3 時間後

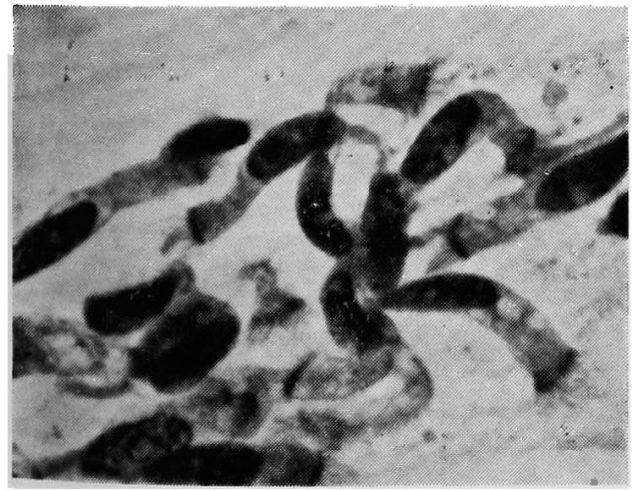

上皮細胞は非常に虽離され易く, 細胞の変形も著 明で, 細胞質内には著明な変性が認められる。
写真 2 正常家香鼻咽腔粘膜

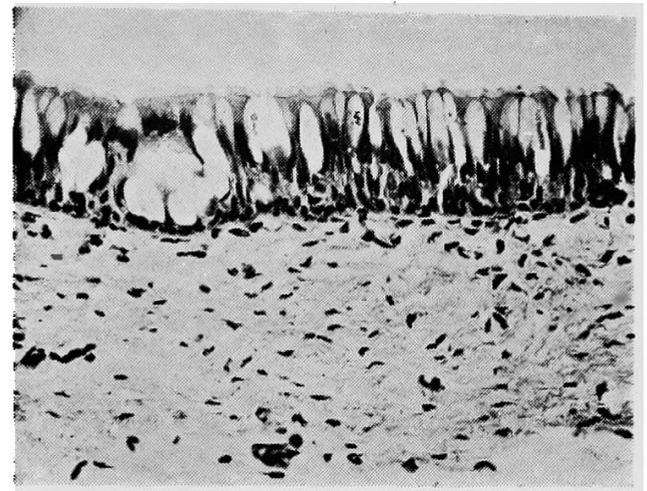

写真 4 注入 1 時間後

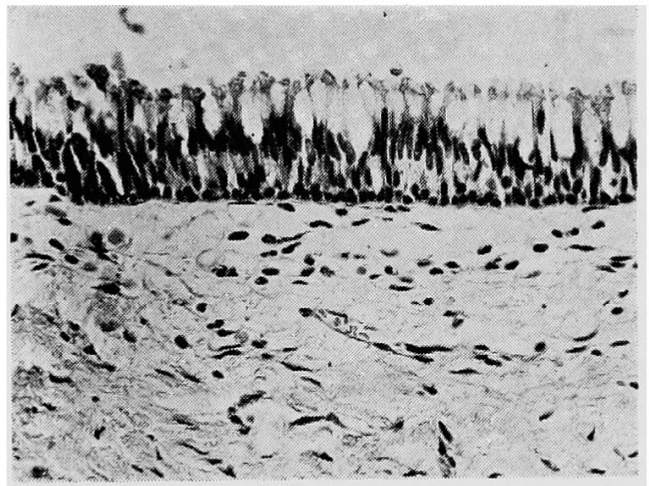

線毛細胞の線毛は不規則に凝集し, 上皮細胞間に 柽度の弛緩がみられ, 固有層には軽度の充血, 水 腫, 紐胞浸潤が認められる。

写真 6 注入 3 時間後

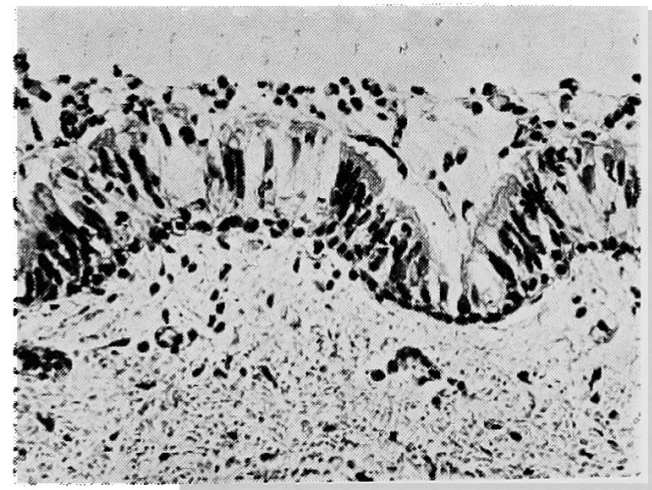

上皮細胞の膨化は著明で, 細胞間の弛緩は增強し, 一部に上皮虽離, 多数の白血球浸潤が認められる。 固有㬝には, 充血, 水腫が著明に認められる。 
写真 7 注入 6 時間後

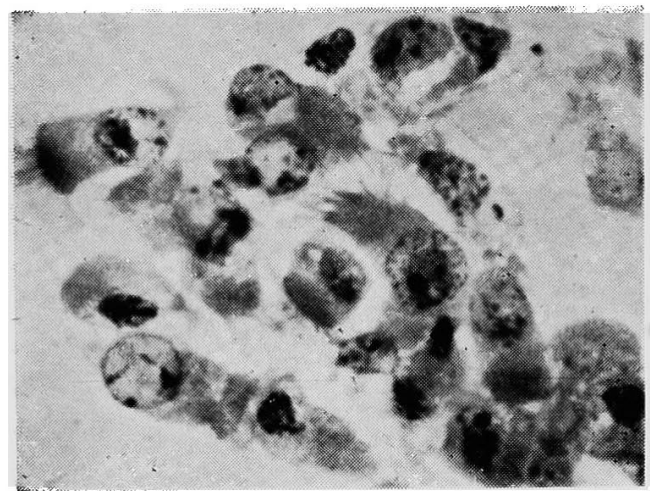

細胞の変性及び変形は著明になり, 線毛の衰失, 細胞質の崩壤, 核の膨大及び核融解, 核膿樎の像 がみられる。

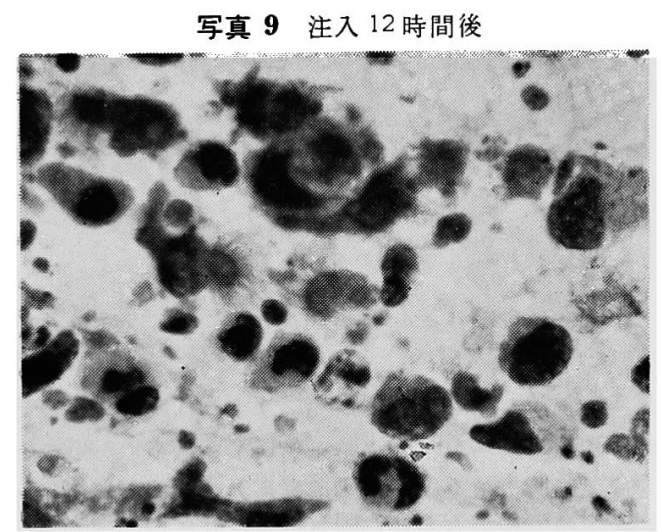

正常な形を有する細胞はなく，上皮細胞は壤れ易 く，紐胞質，核共に高度な変化を示している。

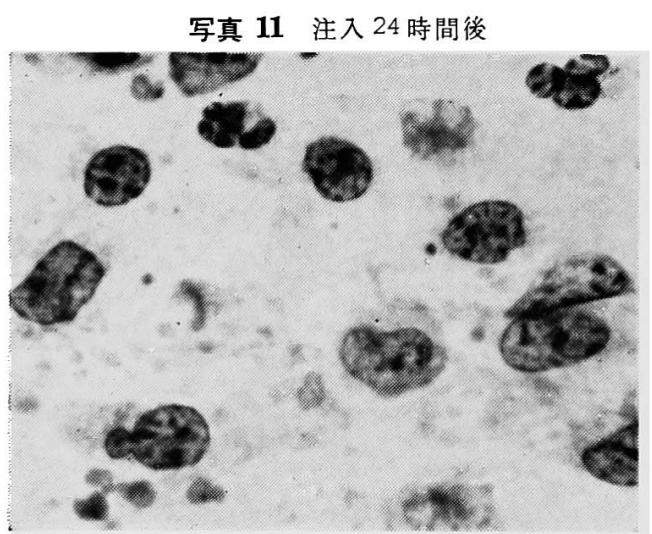

細胞は破壤され，少数の円形乃至棈円形の核を有 する細胞質の不明嘹な細胞が認められる。
写真 8 注入 6 時間後

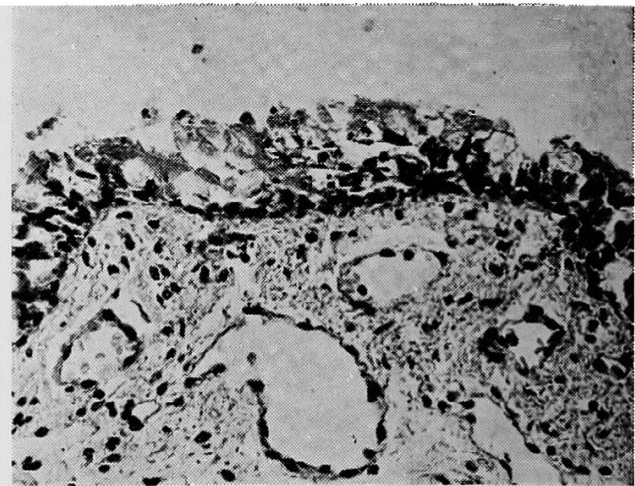

上皮細胞の脱落崩堛が高度にみられ，基底膜上に 補充細胞が認められるにすぎない，固有層では血 管の拡張，水腫，細胞浸潤が著明になる.

写真 10 注入 12 時間後

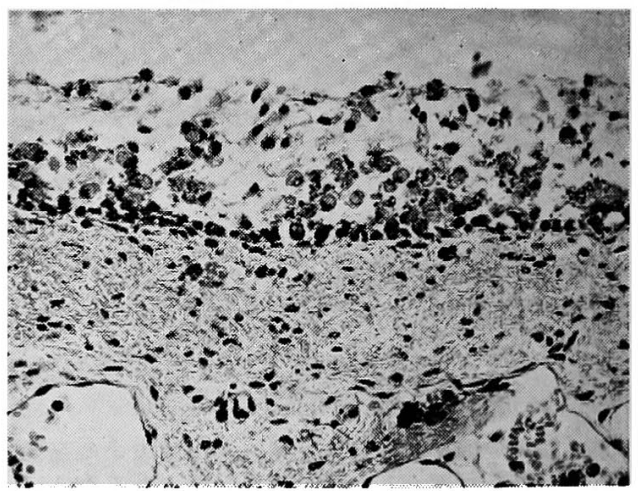

上皮細胞の剝離，破壤は著明で一層の補充細胞が 基底膜の上に存在しているに過ぎない。

写直 12 注入 24 時間後

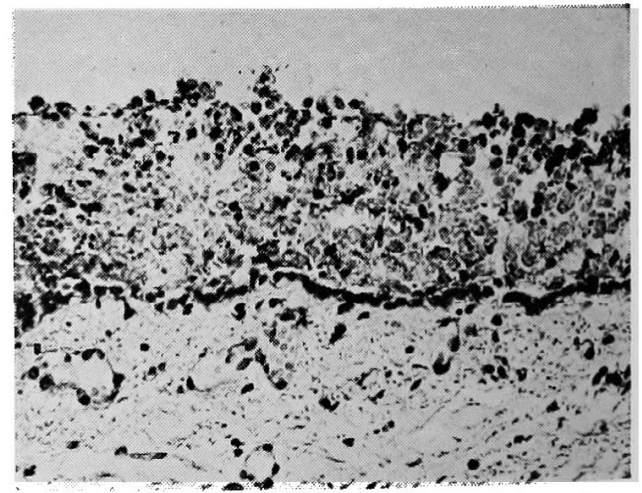

上皮紲胞は破壤, 脱落し, 補充細胞か所々に残つ ているに過ぎない, 病度の強い一部には潰瘍が存 在する. 
写真 13 注入 3 日後

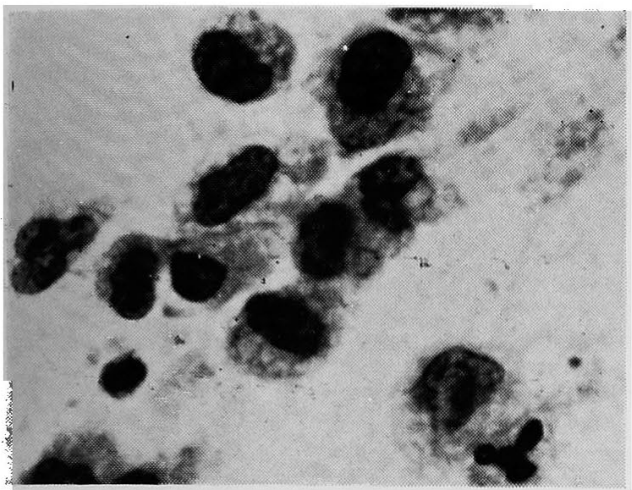

輪廊が明瞭で色質に富む細胞が少数認められる。

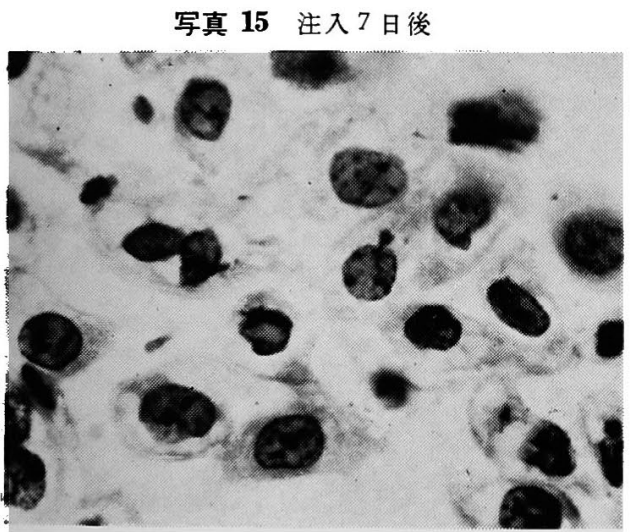

輪廏明瞭な多角形又は円柱上皮細胞が認められる ようになる。

写真 17 注入 14 日後

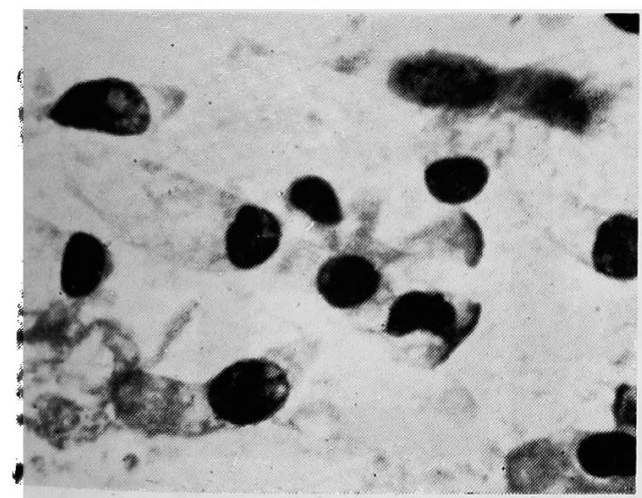

正常の形を有する線毛細胞が出現し, 少数の円柱 細胞, 杯状細胞が認められるようになる。
写真 14 注入 3 日後

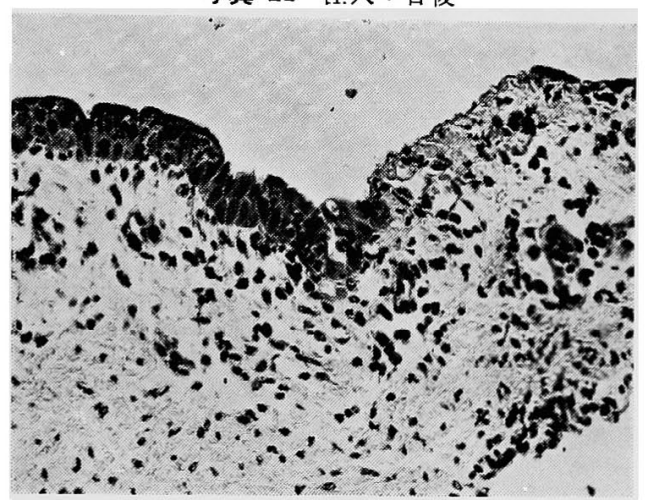

粘膜面には麼翻乃至潰瘍が存在するが，その粼接 部から上皮の再生像が認められる．固有層ではな お血管の桩張, 水腫, 細胞浸潤が認められる。

写真 16 注入 7 日後

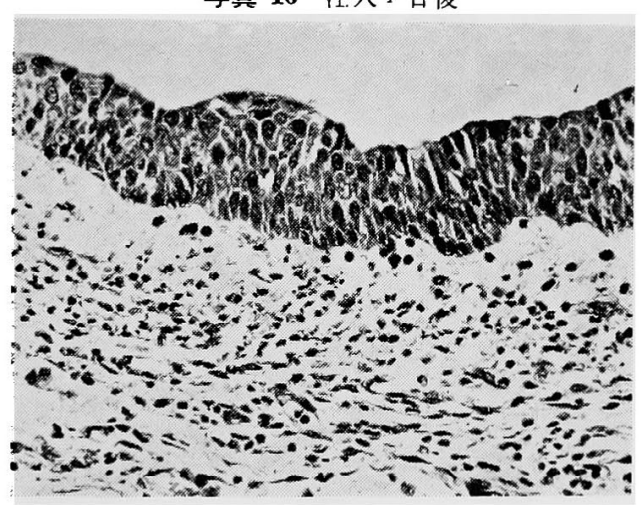

上皮細胞の再生は著明であるが，まだ配列は不規 則である。線毛細胞，杯状細胞はまだ認められず， 固有層では毛細血管の新生, 線維芽細胞の增殖が 見られる。

写真 18 注入 14 日後

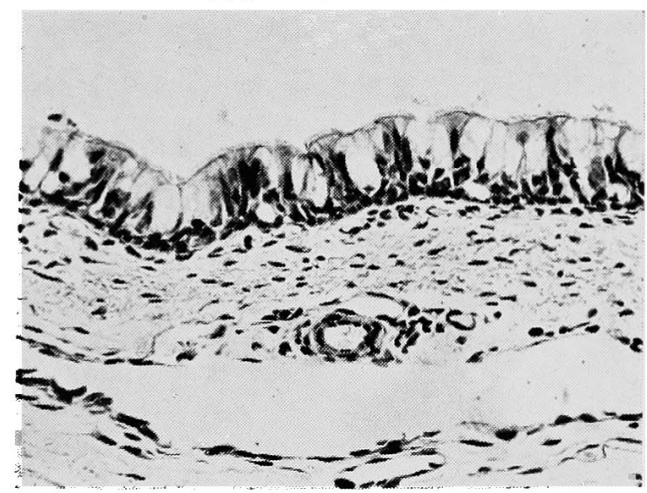

再生上皮の分化が進み, 上皮層は正常な構造に近 くなる。 
写真 19 注入 21 日後

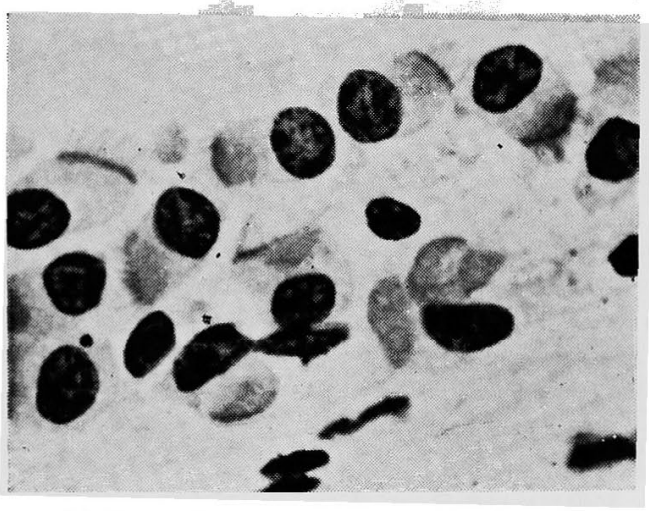

線毛細胞は一般に細胞体の長径が短いもの多いが, 正常な䊔造を有する線毛細胞が多数認められる。

写真 21 注入 28 日後

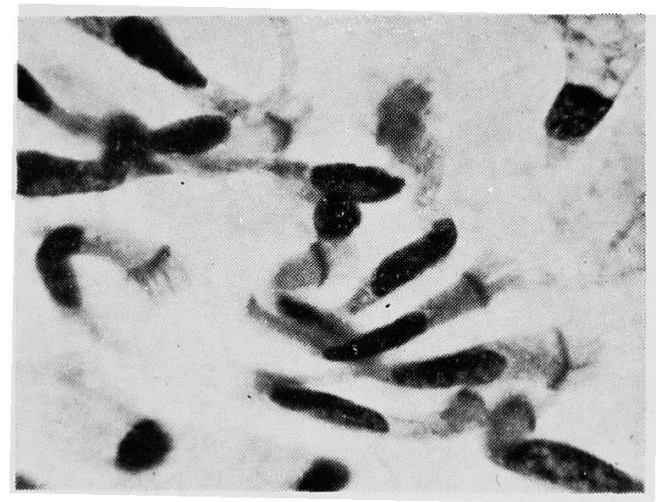

細胞は正常な形を示している。
军真 20 注入 21 日後

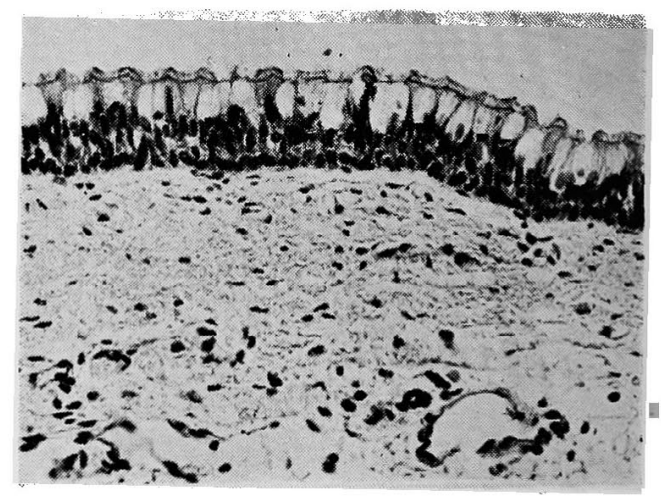

上皮層はほとんど正常に近い構造を示す．固有層 でも炎症性変化はほとんど消失している。

军真 22 沬入 28 日捘

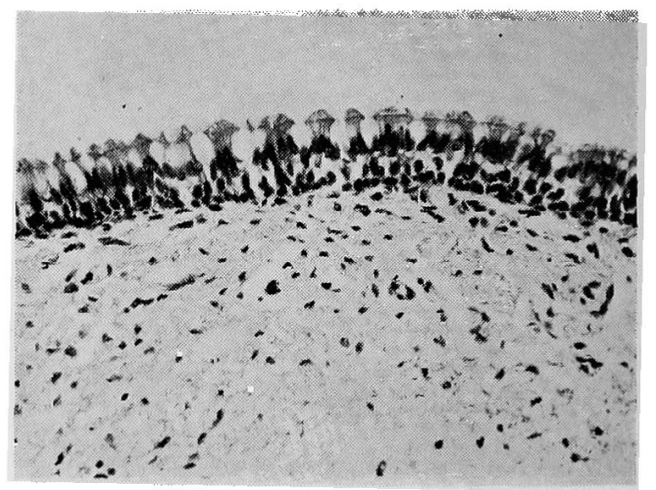

上皮層, 固有層においても炎症性変化は消失す。 